Ekonomia - Wroclaw Economic Review 23/1 (2017)

Acta Universitatis Wratislaviensis

No 3754

DOI: $10.19195 / 2084-4093.23 .1 .2$

\author{
Olga Komorowska \\ Uniwersytet Gdański \\ olga.komorowska@ug.edu.pl
}

\title{
Funkcjonowanie dorosłych osób z niepełnosprawnością w Niemczech
}

\author{
JEL Classification: J14, J21, J24, J28, J38
}

Keywords: work, people with disabilities, support of persons with disabilities in Germany, own budget, benefits for people with disabilities

\section{Abstract}

Functioning adults with disabilities in Germany

In Germany, the issue of prevention of social exclusion of people with disabilities is treated as the primary task of public policy. This article presents German solutions for adults with disabilities thanks to they are integrated into professional and social life. Among these solutions are own budget, job's assistant, work in the professional workshop, support in accomodation, tax breaks, subsidies for rehabilitation equipment.

\section{Wprowadzenie}

W Niemczech kwestia zapobiegania wykluczeniu społecznemu osób z niepełnosprawnością jest traktowana jako podstawowe zadanie polityki społecznej. W roku 2001 weszła w życie ustawa Dziewiąta Księga Kodeksu Socjalnego Rehabilitacja i Partycypacja Osób Niepełnosprawnych (Sozialgesetzbuch SGB IX BGBl. I S. 1046 vom 19.6.2001). Rok później uchwalona została kolejna ustawa dotycząca osób z niepełnosprawnością tzw. Behindertengleichstellungsgesetz BGG (BGBl. I S. 1467, 1468 vom April 2002). Dotyczy ona równego statusu osób niepełnosprawnych.

Niemcy są krajem, w którym obowiązujące prawne rozwiązania oraz podejmowane działania w kierunku integracji osób niepełnosprawnych mają na celu podniesienie poziomu życia osób niepełnosprawnych i aktywne włączenie tych osób w życie społeczne. Zgodnie z zapisami w ustawie osoba z niepełnosprawnością $\mathrm{w}$ Niemczech ma prawo do takiego samego życia jak osoba bez 
niepełnosprawności. Świadczenia (Leistungen zur Teilhabe) przysługujące osobie niepełnosprawnej mają na celu wyrównanie szans osoby niepełnosprawnej i umożliwienie jej podjęcia aktywności zawodowej i włączenia w życie społeczne. Osoba z niepełnosprawnością w Niemczech powinna mieć takie możliwości, żeby samej decydować o wielu rzeczach.

W Niemczech funkcjonują trzy pojęcia, które są związane z włączaniem osób niepełnosprawnych w życie społeczne: Teilhabe, Integration i Inklusion. Teilhabe oznacza włączenie osoby w życie społeczne. Pojęcie ,integracja” uważane jest za przestarzałe, ponieważ oznacza dopasowanie mniejszości albo grupy wykluczonej społecznie do większości, czyli integrująca się grupa pozostaje mimo wszystko odrębną grupą i nie zachodzi prawdziwa wymiana międzyludzka. Inklusion jest najmłodszym pojęciem i dziś bardzo modnym. Oznacza, że ludzie są równi pod względem różnych cech, jak na przykład płeć, inteligencja, fizyczność. Członkowie grupy akceptują siebie nawzajem i wspierają pomimo swoich różnorodności, dzięki czemu grupa staje się homogeniczna. W Niemczech funkcjonuje również pojęcie ,integracja przez inklusję” (Scholz, Haas, Papadopoulos, 2013, s. 7-11).

Celem artykułu jest przedstawienie niemieckich rozwiązań, dzięki którym dorosłe osoby z niepełnosprawnością są włączane (Teilhabe) w życie zawodowe i społeczne. Warto przyjrzeć się rozwiązaniom panującym w Niemczech, ponieważ $\mathrm{z}$ jednej strony są one kompleksowe, $\mathrm{z}$ drugiej natomiast funkcjonują $\mathrm{w}$ tym kraju świadczenia, których w Polsce nie ma. Artykuł został opracowany na podstawie niemieckiej literatury oraz informacji zebranych podczas wizyty studyjnej w Niemczech. Pobyt w Niemczech oraz zakup książek sfinansowany był ze środków NCN w ramach projektu „Zachowania przedsiębiorcze i konsumpcyjne w rodzinach opiekujących się dziećmi i młodzieżą z niepełnosprawnością".

\section{Definicja osoby z niepełnosprawnością}

Definicja osoby z niepełnosprawnością określona jest w art. 2 ustawy Sozialgesetzbuch SGB IX. Osobą niepełnosprawną jest ta, której niepełnosprawność ruchowa, zdolności umysłowe albo zdrowie psychiczne z dużym prawdopodobieństwem przez okres dłuższy niż sześć miesięcy będą ograniczać uczestnictwo w życiu społecznym. Stan zdrowia takiej osoby należy porównać z typowym stanem zdrowia osoby zdrowej w danym wieku. Należy zwrócić uwagę na zakres powyższej definicji. Ograniczenie życia społecznego dotyczy każdego aspektu życia danej osoby — zarówno jej aktywności zawodowej, poruszania się po mieście jak również spędzania czasu wolnego.

Stopień niepełnosprawności (Grad der Behinderung — GdB) określany jest przez interwały - ustalany jest co 10 stopni w skali od 20 do 100. GdB określa wymiar ograniczeń odnoszących się do różnych dziedzin życia zarówno prywatnego jak i zawodowego. Uzyskanie GdB na poziomie co najmniej 50 jest jednym 
z warunków pozwalających na nadanie osobie niepełnosprawnej statusu osoby ze znacznym stopniem niepełnosprawności (Schwerbehinderte) ${ }^{1}$. Orzeczony stopień Schwerbehinderte pozwala na korzystanie z wielu świadczeń wyrównujących szanse osoby niepełnosprawnej (Nachteilsausgleiche) (Komorowska, 2011).

Jedynie osobie z określonym znacznym stopniem niepełnosprawności, czyli posiadającej status Schwerbehinderte, zostaje przyznany symbol niepełnosprawności (Merkzeichen). Należy zaznaczyć, że symbol niepełnosprawności dotyczy nie choroby, lecz sfery funkcjonowania osoby niepełnosprawnej w społeczeństwie i trudności, jakie może napotkać — z wyjątkiem kodu dla osób z niedosłuchem i niewidomych (zob. tabela 1). Na przykład symbol niepełnosprawności G może otrzymać osoba zarówno z chorobą płuc, dla której pokonanie odcinka $2 \mathrm{~km}$ może być bardzo męczące, jak i osoba z upośledzeniem umysłowym, która może nie rozumieć istniejących na ulicy zagrożeń. Przyznanie symbolu niepełnosprawności ma bezpośredni wpływ na otrzymanie odpowiednich świadczeń wyrównujących szanse osoby niepełnosprawnej — na przykład tylko osoba, która otrzymała symbol niepełnosprawności H lub BL, może korzystać z bezpłatnej komunikacji publicznymi środkami transportu.

Tabela 1. Symbole niepełnosprawności obowiązujące w Niemczech

\begin{tabular}{c|l}
\hline Symbol & \multicolumn{1}{c}{ Opis } \\
\hline \multirow{3}{*}{$\mathrm{G}$} & $\begin{array}{l}\text { Gehbehindert — znacznie naruszone zdolności w poruszaniu się w ruchu } \\
\text { ulicznym. } \\
\text { Osoba, która trasę długości do 2 km (pół godziny marszu) pokona z dużymi } \\
\text { trudnościami lub będzie podczas tej drogi narażona na zagrożenia z powodu } \\
\text { własnego zachowania lub podjętych decyzji. }\end{array}$ \\
\hline \multirow{2}{*}{$\mathrm{aG}$} & $\begin{array}{l}\text { aussergewöhnlich Gehbehindert } \\
\text { Na skutek swoich chorób może poruszać się przy pomocy osoby trzeciej lub } \\
\text { sama, ale z wielkim trudem. } \\
\text { Do takich osób zalicza się między innymi osobę, która ma amputowane oba } \\
\text { ramiona, osobę z chorobami serca lub płuc z stopniem GdB powyżej 80, osobę } \\
\text { z porażeniem dolnej części ciała. }\end{array}$ \\
\hline $\mathrm{GL}$ & \begin{tabular}{l} 
Gehörlos — osoba niesłysząca \\
\hline
\end{tabular}
\end{tabular}

${ }^{1}$ Drugim warunkiem mającym wpływ na otrzymanie statusu Schwerbehinderte jest fakt posiadania legalnego miejsca zamieszkania, pobytu oraz miejsca pracy. Osoba niepełnosprawna ze stopniem niepełnosprawności GdB niższym niż 50, ale większym niż 30 ma również możliwość otrzymania statusu Schwerbehinderte, jednak jedynie, gdy bez wsparcia wynikającego z przepisów prawa nie otrzyma pracy albo nie będzie mogła utrzymać dotychczasowego stanowiska pracy. 


\begin{tabular}{|c|c|}
\hline $\mathrm{RF}$ & $\begin{array}{l}\text { Rundfunkgebührenbefreiung } \\
\text { Osoba zwolniona z opłat radiofonicznych. } \\
\text { Symbol RF na legitymacji otrzymają osoby z problemami w poruszaniu się, } \\
\text { które potrzebują pomocy osoby trzeciej albo pomocy urządzeń technicznych, } \\
\text { żeby wziąć udział w publicznej imprezie. Dotyczy to również osób z upośle- } \\
\text { dzeniem umysłowym, przy których jest obawa, że przez swoje zachowanie } \\
\text { będą przeszkadzać innym osobom podczas zorganizowanej imprezy. Będą to } \\
\text { również osoby niepełnosprawne, które z powodu swojej niepełnosprawno- } \\
\text { ści oddziałują odpychająco lub uciążliwie na środowisko. Kod RF otrzyma } \\
\text { również osoba chora na gruźlicę (w stopniu ciężkim), osoby z uszkodzeniem } \\
\text { wzroku (GdB przynajmniej 60) oraz osoba z uszkodzeniem słuchu (GdB przy- } \\
\text { najmniej 50). }\end{array}$ \\
\hline $\mathrm{H}$ & $\begin{array}{l}\text { Hilflos } \\
\text { Na skutek swojej niepełnosprawności w codziennym życiu potrzebuje } \\
\text { wsparcia innej osoby. Pomoc osoby trzeciej musi być ciągła. } \\
\text { Na przykład: osoby niewidzące (GdB 100), z upośledzeniem umysłowym } \\
\text { (GdB 100), osoby z porażeniem dolnej części ciała, które również w domu } \\
\text { muszą poruszać się za pomocą wózka inwalidzkiego. }\end{array}$ \\
\hline $\mathrm{BL}$ & Blind - osoba niewidoma \\
\hline $\mathrm{B}$ & $\begin{array}{l}\text { Begleitperson } \\
\text { Osoba potrzebująca ciągłej pomocy osoby trzeciej w celu uniknięcia } \\
\text { niebezpieczeństw, które mogąjejzagrażaćw związkuzjejniepełnosprawnością. } \\
\text { Osoba, która potrzebuje pomocy osoby trzeciej przy korzystaniu z publicznych } \\
\text { środków transportu. } \\
\text { Na przykład: osoby niewidome, osoby z porażeniem dolnej części ciała, osoby } \\
\text { niesłyszące, osoby z upośledzeniem umysłowym. }\end{array}$ \\
\hline $1 \mathrm{KL}$ & Osoba jest niepełnosprawna na skutek działań wojennych i prześladowań. \\
\hline
\end{tabular}

Źródło: Greß, 2013, s. 27-28; Komorowska 2011, s. 311-321.

\section{Pomoc we włączeniu się do życia}

\subsection{Własny budżet}

O uzyskanie prawa do własnego budżetu może ubiegać się każda osoba z niepełnosprawnością fizyczną, umysłową oraz psychiczną. Własny budżet jest świadczeniem, które powoduje zmiany w relacji między osobą niepełnosprawną a otoczeniem, ponieważ osoba niepełnosprawna może zrezygnować ze świadczenia na rzecz „własnego budżetu”. Otrzymuje środki pieniężne, za które sama dokonuje zakupu usługi lub opłaca świadczeniodawcę. Przy przyznaniu środków obowiązuje zasada, że przyznana kwota nie może być wyższa niż wartość dotychczas 
otrzymywanego świadczenia rzeczowego. Uprawnienia do otrzymywania „własnego budżetu" mają osoby niepełnosprawne lub osoby zagrożone niepełnosprawnością, niezależnie od wieku, sytuacji ekonomicznej oraz stopnia niepełnosprawności.

Środki otrzymane w ramach „własnego budżetu” mogą być przeznaczone na świadczenia i usługi różnego typu, na przykład na pokrycie kosztów asystenta w miejscu pracy, na pokrycie kosztów osoby, która zaopiekuje się osobą niepełnosprawną w jej czasie wolnym, na pokrycie kosztów związanych z uzyskaniem praktycznych umiejętności, na pokrycie kosztów w pomocy w komunikowaniu się.

Świadczenie wypłaca instytucja, która jest odpowiedzialna za dane wsparcie. Na przykład jeżeli środki mają być przeznaczone na asystenta w pracy, wypłaci agentura ds. pracy (Agentur für Arbeit), jeżeli natomiast środki mają być przeznaczone na sfinansowanie terapeuty rehabilitanta, środki wypłaci kasa opieki (Pflegekasse) lub kasa chorych (Krankenkasse). W sytuacji gdy są wypłacane środki z własnego budżetu, a jest kilka instytucji odpowiedzialnych za ich wypłatę, osoba niepełnosprawna zwraca się do jednego podmiotu, z nim podpisuje umowę, natomiast zaangażowane instytucje mają obowiązek komunikowania się między sobą i przekazywania między sobą rozliczeń.

Należy zwrócić uwagę, że korzystanie z tego świadczenia stawia wysokie wymagania osobom niepełnosprawnym. Osoby te muszą podejmować samodzielnie wiele decyzji (między innymi w jakim celu zostaną wydane pieniądze, kto będzie pomagał oraz kiedy będzie pomagał). Muszą samodzielnie zarządzać środkami finansowymi, tak aby potrzeby, na które środki były przeznaczone, zostały sfinansowane $\mathrm{w}$ danym miesiącu. Własny budżet jako świadczenie pieniężne jest zwolnione z podatku. Jednak zatrudniając asystenta (osobę do pomocy), osoba niepełnosprawna staje się pracodawcą, na którym ciążą obowiązki podatkowe i ubezpieczeniowe ${ }^{2}$. Niektórym osobom niepełnosprawnym podejmowanie wymienionych działań i decyzji może sprawiać trudność. W takiej sytuacji pomoc można znaleźć u rodziców lub u prawnego opiekuna. Można również opłacić $\mathrm{z}$,własnego budżetu” osobę, która będzie doradcą i pomocą w rozliczaniu pieniędzy (Greß, 2013, s. 85-87; Komorowska, 2011a).

\subsection{Praca na otwartym rynku pracy}

Każda niemiecka firma zatrudniająca przynajmniej 20 osób jest zobowiązana zatrudnić osobę niepełnosprawną (Schwerbehinderte). Zakład pracy otrzyma wsparcie finansowe na dostosowanie stanowiska pracy do potrzeb pracownika z niepełnosprawnością. Jeżeli zakład pracy nie spełni warunku zatrudnienia, musi zapłacić karę.

${ }^{2}$ INFO - Persönliches Budget. Frage zur Steuerpflicht, s. 2. 
Osoba niepełnosprawna ma prawo do uzyskania wsparcia w postaci asystenta przy pracy. Asystent ma za zadanie wspomóc w pracy, na przykład przeczytać list, podać z półki dokumenty, wytłumaczyć zasady funkcjonowania działu w firmie.

Pracownik z orzeczoną niepełnosprawnością ma prawo do dodatkowego tygodnia urlopu. Nie może pracować w nocy oraz w nadgodzinach. Osoba niepełnosprawna nie może zostać zwolniona bez zgody Urzędu ds. Integracji (Integrations-Amt). Urząd ten wyraża również zgodę na przeniesienie osoby z niepełnosprawnością na inne stanowisko.

Pani Sabine - matka 25 letniego Mathiego:

Mathi ma teraz lat 25. Ma zespół Downa. Mieszka sam. Przychodzi do niego asystent i pomaga mu w płaceniu rachunków. Uczy go, które produkty może kupować, ponieważ Mathi kupowałby tylko czekoladę. Mathi pracuje. Dojeżdża sam do pracy. Pracuje na rynku otwartym. Dwa lata trwało jego wdrażanie do pracy. Wspierał go asystent. Uczył go, jak funkcjonuje firma, jak ma realizować swoje zadania. Teraz asystent przychodzi w razie potrzeby. Mathi układa towar na półkach, roznosi pocztę.

\subsection{Warsztaty zawodowe}

Celem pracy w warsztatach zawodowe (WfbM - Werkstatt fur behinderte Menschen) jest nauka oraz przygotowanie osób do pracy. Proces przygotowania (Ausbildung) rozłożony jest w czasie. W WfbM osoby z niepełnosprawnością podzielone są na grupy wykonujące proste czynności, jak na przykład pakowanie, i na grupy, które wykonują trudniejsze czynności, np. produkcja mebli, szycie odzieży roboczej, świadczenie usług, np. serwis rowerowy, katering ${ }^{3}$. Osoby będące podopiecznymi WfbM mają ubezpieczenie chorobowe, otrzymują wynagrodzenie za swoją pracę, za drogę do WfbM nie ponoszą opłat. Co należy podkreślić, praca w WfbM nie jest uważana w Niemczech za rehabilitacją zawodową. Podopieczni wytwarzają produkty, które są dostarczane na rynek. Jest to możliwe, ponieważ niemieckie firmy mają obowiązek dokonywania pewnego procentu zakupu towarów i usług z organizacjach typu warsztat zawodowy. W Wfbm osoba z niepełnosprawnością ma możliwość uczestniczenia w zajęciach rehabilitacyjnych (Greß, 2014, s. 18).

Jednak WfbB poddawane są w ostatnim czasie krytyce ze względu na to, że ograniczają osobom niepełnosprawnym branie udziału w normalnym życiu, a nawet wręcz je wykluczają. Koncepcja WfbB jest niezgodna z inkluzją (Günther, 2015, s. 15).

Pani Karina - matka 25 letniej Anny:

Anna ma teraz 25 lat. Ma niepełnosprawność umysłową, padaczkę, orzeczony stopień opieki Pflegestufe II. Anna jeździ co dziennie busem do warsztatu terapii zajęciowej Norderstedter Werkstätten. Przepakowuje różne rzeczy. Jest tam już 7 lat, od 7.30 do 16.00. To jest łatwa praca. Anna jest zadowolona. W ciągu dwóch lat zrobiła kształcenie w miejscu pracy (Ausbildung) ze sprzątania,

3 http://www.elbe-werkstaetten.de/ [dostęp: 2.06.2016]. 
aspektów socjalnych oraz z praktycznych rzeczy, które jej się przydadzą w życiu (lebenspraktische Bereiche). Oprócz pracy w warsztacie przeprowadzane są zajęcia z logopedą, pedagogiem, psychologiem. Jest rehabilitacja. W tym warsztacie terapii zajęciowej jest 320 podopiecznych, 100 specjalistów. Część podopiecznych wykonuje trudniejsze prace, na przykład robią meble, wyroby z metali. Praca jest wykonywana na rzecz innych firm.

\subsection{Dzienne domy pomocy społecznej}

Dzienne domy pomocy społecznej (Förderstätte) świadczą opiekę dzienną nad osobami z upośledzeniem w stopniu znacznym. Podopieczni tej instytucji mają zapewnioną edukację dostosowaną do swojego poziomu, zajęcia rehabilitacyjne, hipoterapię, spacer, obiad ${ }^{4}$. Osoby te są przywożone busem, jeżeli mieszkają poza własnym domem rodzinnym, albo przez swoich rodziców, którzy się nimi opiekują.

Pan Jan — lat 43 (dzienny dom pomocy tzw. Förderstätte Himmelmoor):

Pan Jan ma zespół Downa. Jeszcze trzy lata temu sam dojeżdżał do WTZ. W tej chwili poziom jego rozwoju jest na poziomie małego dziecka. Mieszka w domu, w którym mieszkają również inne osoby z niepełnosprawnością. Przyjeżdża mikrobusem z miejsca zamieszkania do dziennego domu pomocy. Tam je śniadanie, śpiewa piosenkę, wykonuje proste ćwiczenia jak na przykład wkładanie klocków w odpowiednie otwory, idzie z grupą na spacer, je obiad. O godzinie 15 przyjeżdża mikrobus i zawozi go z powrotem do jego miejsca zamieszkania.

\subsection{Pomoc związana z mieszkaniem}

Kasa opieki (Pflegekasse) udzieli dofinansowania na dostosowanie mieszkania do potrzeb osób z niepełnosprawnością w wysokości nie wyższej niż 2557 EUR. Pracownicy kasy opieki sami oceniają zasadność wniosku o dofinansowanie. Z kolei kasa chorych (Krankenkasse) zagwarantuje środki pomocnicze (np. deska do siedzenia pod prysznicem), które ułatwią życie osobie z niepełnosprawnością w mieszkaniu. W tym przypadku warunkiem uzyskania wsparcia finansowego jest otrzymanie recepty od lekarza.

Osoby z niepełnosprawnością w Niemczech mają dostęp do różnych form zamieszkania. W instytucjach stacjonarnych opieka trwa 24 godziny na dobę. Zapewnione jest także spędzenie czasu wolnego. Do tej formy wsparcia mieszkania zalicza się: Wohnheime, Dorfgemeinschaften, eigenstandige WohnGruppe. Koszty zamieszkania pokrywa instytucja odpowiedzialna za pomoc socjalną. Podopieczny otrzymuje kieszonkowe w wysokości 105,57 EUR miesięcznie. Inną formą mieszkalnictwa jest wspólne mieszkanie od 4 do 8 osób z niepełnosprawnością (betreuten Wohngemeinschaften). Osoby te otrzymują pomoc i wsparcie, ale nie przez 24 godziny na dobę. Ich opiekun doradza im w prowadzeniu gospodarstwa domowego. Osoby, które mieszkają w betreuten Wohngemeinschaften są w stanie pozostać długo bez opieki i organizować sobie same dzień. Kolejnym sposobem

${ }^{4}$ http://www.bf-himmelmoor.de/ [dostęp: 2.06.2016]. 
na mieszkanie jest mieszkanie samodzielne (betreute Einzelwohnen). Ta forma zamieszkania dotyczy osób, które są w wysokim stopniu samodzielne i potrzebują tylko niewielkiego wsparcia osoby trzeciej. W kosztach zamieszkania partycypuje też i w tym przypadku instytucja państwowa. Do osoby, która mieszka w betreute Einzelwohnen, przychodzi w miarę potrzeby asystent, aby pomóc i doradzić w kwestiach problematycznych (Gre $\beta, 2014$, s. 150-157).

\section{Dochody i ulgi podatkowe}

\subsection{Dofinansowanie do samochodu}

Prawo niemieckie przewiduje dofinansowanie do samochodu osobie z niepełnosprawnością. Wsparcie można otrzymać przy zakupie samochodu odpowiednio dużego i dostosowanego do potrzeb osoby z niepełnosprawnością. Można je otrzymać na pokrycie kosztów prawa jazdy, a także na pokrycie kosztów zastosowania dodatkowego wyposażenia samochodu. Wysokość dofinansowania wynosi maksymalnie 9500 EUR i jest uzależniona od uzyskiwanych miesięcznie dochodów. Na przykład dofinansowanie w wysokości 9500 EUR dotyczy osób, których zarobki w miesiącu nie przekroczyły 1080 EUR. Natomiast jeżeli osoba miesięcznie zarabia 2025 EUR, uzyska dofinansowanie w wysokości dużo niższej, bo 1520 EUR. Dofinansowanie może dotyczyć też używanego samochodu, ale tylko, gdy jego wartość nie jest niższa niż 50\% wartości nowego samochodu. (Greß, 2013, s. 48).

\subsection{Ulga podatkowa}

Prawo podatkowe przewiduje ulgi podatkowe dla osób z niepełnosprawnością, ze względu na to, że osoby te ponoszą wyższe koszty życia. Ulgi podatkowe dotyczą także rodzin, które opiekują się osobą z niepełnosprawnością.

Osobom z niepełnosprawnością przysługuje tzw. ryczałtowa kwota (Pauschbetrag), którą uwzględnia się w rocznym zeznaniu podatkowym (Einkommensteuererklärung) w celu obniżenia podatku za poprzedni rok. Wysokość tej kwoty uzależniona jest od stopnia niepełnosprawności — wraz ze zwiększoną niepełnosprawnością wysokość tej ulgi jest większa. Na przykład przy stopniu niepełnosprawności od 25 do 30 przysługuje kwota ryczałtowa w wysokości 310 EUR, następnie przy niepełnosprawności od 35 do 40 ulga ta wynosi 430 EUR. Przy stopniu niepełnosprawności 65 i 80 kwota ta wynosi 1060 EUR. Osoba mająca najwyższy stopień niepełnosprawności od 95 do 100, ma prawo do 1420 EUR ulgi. Do jeszcze wyższej kwoty ryczałtowej ma prawo osoba z symbolem niepełnosprawności H oraz $\mathrm{Bi}$ - ulga dla tych osób wynosi 3700 EUR. (Kruse, 2011, s. 8; Steuerwegweiser für behinderte Menschen, s. 8-12; Gre $\beta, 2013$, s. 41-44). Od 2009 r. w Niemczech obowiązuje podatek od spalin (Kraftfahrzeugsteuer). Osoby z niepełnosprawnością określoną symbolem $\mathrm{H}$, BI albo aG mogą zostać 
zwolnione z obowiązku płacenia tego podatku. Mogą także ubiegać się o dofinansowanie do poniesionych kosztów w komunikacji publicznej. Natomiast osoby z orzeczoną niepełnosprawnością G i GI mają prawo do $50 \%$ ulgi w podatku od spalin i $100 \%$ ulgę w płatnościach w publicznej komunikacji. Warunkiem otrzymania ulgi od spalin jest fakt, że właścicielem samochodu jest osoba $\mathrm{z}$ niepełnosprawnością. Nie jest wystarczającym warunkiem posiadanie przez osobę z niepełnosprawnością prawa jazdy (Greß, 2013, s. 49).

\subsection{Dofinansowanie}

W Niemczech osoby z niepełnosprawnością mogą ubiegać się o dofinansowanie do sprzętu rehabilitacyjnego, przedmiotów ortopedycznych oraz środków pomocniczych $(\text { Hilfsmittel })^{5}$ i uzyskanie większej samodzielności. O wysokości zapotrzebowania decyduje lekarz. W Niemczech tzw. techniczny środek pomocniczy, np. kula czy wózek, są własnością kasy chorych i po skończonym okresie użytkowania osoba niepełnosprawna musi zwrócić używany środek pomocniczy do kasy chorych. Jednak otrzymując środek pomocniczy z kasy chorych, musi do niego dopłacić ustaloną kwotę (Zuzahlung), według podanej zasady: 10\% ceny środka pomocniczego, jednak nie mniej niż 5 EUR, a maksymalnie 10 EUR (dopłata nie może być wyższa niż cena środka pomocniczego). W przypadku zakupu środka pomocniczego do jednorazowego użytku (np. pieluchy) dopłata wynosi $10 \%$ ceny opakowania (np. opakowania pieluch), jednak maksymalnie 10 EUR na miesiąc. Wszystkie dopłaty (Zuzahlung) do środków pomocniczych osoba ubezpieczona ponosi w ciągu roku jedynie do ustalonej granicy (Belastungsgrenze). W przypadku niektórych środków pomocniczych ${ }^{6}$ określony jest tzw. próg płatności (Festbetrag) ${ }^{7}$, czyli próg, do którego wysokości kasa chorych ponosi koszty.

Gdy osoba ma jeden z trzech stopni opieki (Pflegestufe), ma prawo do otrzymania z kasy opieki środek pomagający w pielęgnacji (Pflegehilfsmittel). Celem takiego środka jest zmniejszenie dolegliwości chorobowych lub umożliwienie prowadzenia samodzielnego życia. Podstawowym warunkiem otrzymania pomocy jest nieotrzymywanie wsparcia $\mathrm{w}$ tym zakresie z kasy chorych. Wysokość pomocy uzależniona jest od rodzaju środka. W przypadku środków zużywających się, jak np. pieluchy, miesięczne dofinansowanie wynosi maksymalnie 31 EUR. W przypadku technicznych środków pomocniczych, kasa opieki dopłaca $10 \%$ poniesionych kosztów, jednak nie więcej niż 25 EUR (Röger, 2010, s. 41-44; http:// www.intakt.info/103-0-zuzahlung-fuer-hilfsmittel-und-medikamente.html).

5 Kasa chorych nie jest odpowiedzialna za dofinansowanie środków wspierających funkcjonowanie osoby niepełnosprawnej w miejscu pracy lub na studiach.

${ }^{6}$ Wkładki ortopedyczne do butów, pomoc w słyszeniu, pomoc w widzeniu, sprzęt stomijny, sprzęt pomagający w nietrzymaniu moczu, Kompressionterapie.

7 Kwota ta jest ustalana przez Główny Związek Kas Chorych (Spitzenverbände der Krankenkasse) i obowiązuje w całych Niemczech. 


\section{Inne}

W Niemczech osoba z niepełnosprawnością ma prawo do wielu innych usług — na przykład darmowy przejazd komunikacją miejską (dotyczy to osób z problemami w poruszaniu się). Osoby z niepełnosprawnością określoną symbolem aG oraz BI otrzymują kartę parkingową, która zwalnia z opłat parkingowych w mieście, pod warunkiem że zaparkuje samochód na specjalnie przygotowanym do tego celu miejscu. Karta parkingowa umożliwia również przekroczenie czasu parkowania.

\section{Wnioski}

W Sozialgesetzbuch SGB IX zatytułowanym Rehabilitacja i partycypacja osób niepełnosprawnych w $\S 1$ można przeczytać:

Osoby niepełnosprawne i zagrożone niepełnosprawnością otrzymują określone w tym kodeksie świadczenia, których celem jest wspieranie decydowania o samym sobie (Selbstbestimmung) oraz uczestniczenie $\mathrm{w}$ życiu społeczeństwa na równych prawach z innymi. Ważne przy tym są szczególne potrzeby kobiet i dzieci ${ }^{8}$.

Wydaje się, że zapis z ustawy jest realizowany w praktyce przez społeczeństwo niemieckie.

Ciekawym rozwiązaniem w Niemczech są symbole niepełnosprawności. W większości nie określają one choroby, lecz dysfunkcje, z którymi zmaga się osoba z niepełnosprawnością. Wsparcie ukierunkowane jest nie na chorobę, lecz na pokonanie przeszkód, dzięki czemu osoba z niepełnosprawnością będzie mogła funkcjonować na równych prawach w społeczeństwie.

Funkcjonujące w Niemczech rozwiązanie, jakim jest ,własny budżet”, powoduje, że osoba z niepełnosprawnością ma możliwość dokonywania wyborów w odniesieniu do swojej osoby, wzmacniana jest jej samodzielność. Wsparcie jest dostosowane do indywidualnych potrzeb tej osoby.

„Własny budżet” jest rozwiązaniem, które mogłoby pozytywnie wpłynąć na zwiększenie aktywności osób niepełnosprawnych w Polsce zarówno w sferze społecznej, kulturalnej, edukacyjnej, jak i zawodowej. Własny budżet wpływa również na zwiększenie poziomu usług dla osoby z niepełnosprawnością, ponieważ to ona sama wybiera kto, gdzie i kiedy ma ją wspierać. Świadczenie to umożliwia funkcjonowanie osobie niepełnosprawnej w życiu społeczeństwa na szeroką skalę, ponieważ nie jest ona złączona z jednym ośrodkiem wspierającym. Należy podkreślić, że ważną rzeczą przy wypłacie tego świadczenia jest współpraca mię-

8 Oryginalny zapis w języku niemieckim: „Behinderte oder von Behinderung bedrohte Menschen erhalten Leistungen nach diesem Buch und den für die Rehabilitationsträger geltenden Leistungsgesetzen, um ihre Selbstbestimmung und gleichberechtigte Teilhabe am Leben in der Gesellschaft zu fördern, Benachteiligungen zu vermeiden oder ihnen entgegenzuwirken. Dabei wird den besonderen Bedürfnissen behinderter und von Behinderung bedrohter Frauen und Kinder Rechnung getragen". 
dzy instytucjami. Świadczenie to często finansowane jest przez kilka instytucji, natomiast wypłaca je jedna instytucja, z którą osoba z niepełnosprawnością podpisuje umowę.

Ważnym wsparciem, które działa w Niemczech, jest asystentura. Asystent wspiera osobę z niepełnosprawnością $\mathrm{w}$ pracy, asystent wspiera osobę z niepełnosprawnością w spędzaniu czasu wolnego, jak również uczy życia dnia codziennego.

Należy przyjrzeć się zasadom, według których funkcjonują warsztaty zawodowe. Warsztat terapii zajęciowej jest podmiotem ekonomicznym na rynku. Jest partnerem biznesowym innych firm, co podnosi rangę osób z niepełnosprawnością $\mathrm{w}$ społeczeństwie. Osoby z niepełnosprawnością mają poczucie, że wnoszą pewną wartość do społeczeństwa.

\section{Bibliografia}

Behindertengleichstellungsgesetz vom 27. April 2002 (BGBl. I S. 1467, 1468).

Greß J. (2013), Schwerbehindert. Meine Rechte: Wohnen,Arbeiten, Steuern und Mobiltät, München. Gre $\beta$ J. (2014), Recht und Förderung für mein behindertes Kind, München.

Günther G. (2015), Berufliche Ausbildung junger Menschen mit Behinderung, Bertelsmann W. Verlag, Bielefeld.

Komorowska O. (2011), Osoba niepetnosprawna w Polsce $i$ w Niemczech - wybrane aspekty praw$n e$, ,Studia Prawno-Ekonomiczne” LXXXIII.

Komorowska O. (2011a), Własny budżet - nowa forma świadczeń dla osób z niepetnosprawnościa w Niemczech, „Prace i Materiały Wydziału Zarządzania Uniwersytetu Gdańskiego”, nr 2/3.

Kruse K. (2011), Steuermerkblatt für Familie mit behinderten Kinder, Bundesverband für körperund mehrfachbehinderte Menschen e.V., Düsseldorf.

Ritz H. (2015), Teilhabe von Menschen mit wesentlichen Behinderungen am Arbeitsmarkt, Friedrich-Ebert-Stiftung.

Röger B. (2010), Finanzielle Hilfen für Menschen mit Behinderung, Walhalla-Regensburg.

Scholz T., Haas F., Papadopoulos H, (2013), Das Recht auf Arbeit, Norderstedt.

Sozialgesetzbuch Neuntes Buch Rehabilitation und Teilhabe behinderter Menschen (SGB IX), z dnia 19 czerwca 2001 (BGB1. I S. 1046).

\section{Źródła internetowe}

http://www.bf-himmelmoor.de/.

http://www.elbe-werkstaetten.de/. 